\title{
Effect of pesticide types on community structure of arthropod in soy crops
}

\author{
Pengaruh jenis pestisida terhadap struktur komunitas artropoda \\ pada pertanaman kedelai
}

\author{
Dwi Ristyadi ${ }^{1 *}$, Nigel Andrew ${ }^{2}$, Rachel Waugh ${ }^{2}$ \\ ${ }^{1}$ Agroekoteknologi, Fakultas Pertanian, Universitas Jambi \\ Jalan Raya Jambi-Muara Bulian, Km 15, Mendalo Darat 36361 \\ ${ }^{2}$ School of Environmental \& Rural Science, University of New England \\ Elm Avenue, Armidale. NSW. 2351. Australia
}

(diterima Juli 2013, disetujui Agustus 2013)

\begin{abstract}
This study was carried out on three soybean farms located in the Liverpool Plains Shire in New South Wales, Australia. The soybean farms were different in terms of pesticide type used. One of the soy crops was sprayed with broad spectrum synthetic pesticides (synthetic pyrethroids), one site of soy crop was sprayed with natural pyrethrum - an organically certified pesticide, and one of the soy crops was not treated with any pesticides. Arthropod samples were collected on three occasions at every site except in the third site of soy crops which was not treated with any pesticides. Samplings were done using sweep nets and beat sheets. There were no significant differences of community structure change between farms treated with different pesticide regimes $\left(\mathrm{F}_{2,5}=4.2599, \mathrm{P}_{(\mathrm{perm})}=\right.$ 0.188 ), and no significant differences in arthropod species richness. The abundance of arthropods was significantly different for site treated with biopesticide and site treated with synthetic pyrethroids $\left(\mathrm{G}_{6}=284.36, \mathrm{P}<0.0001\right)$, non-sprayed site and site treated with synthetic pyrethroids $\left(\mathrm{G}_{6}=2110, \mathrm{P}\right.$ $<0.0001)$, and non-sprayed site to site treated with biopesticide $\left(\mathrm{G}_{6}=2027, \mathrm{P}<0.0001\right)$. The use of synthetic pesticides in agriculture has been found to suppress pests and beneficial arthropods, while the use of biopesticides or without pesticide, to some extent, may let beneficials thrive in the system and also may suppress pest arthropods.
\end{abstract}

Key words: arthropods, soy-bean, pesticides, organic farming, conventional farming

\begin{abstract}
ABSTRAK
Penelitian dilaksanakan di tiga pertanaman kedelai yang terletak di Liverpool Plains Shire, New South Wales, Australia. Pertanaman kedelai tersebut berbeda dalam hal penggunaan pestisida, yaitu menggunakan pestisida sintetik berspektrum luas (pyrethroids sintetik), menggunakan biopestisida (pyrethrum alami), dan tanpa menggunakan pestisida. Pengambilan sampel artropoda dilaksanakan dengan menggunakan jaring ayun (sweep nets) dan beat sheets. Pengambilan sampel dilaksanakan tiga kali pada tiap lokasi, kecuali pada lokasi yang tanpa pestida hanya dilakukan dua kali pengambilan sampel. Tidak terdapat perbedaan yang nyata pada perubahan struktur komunitas artropoda di pertanaman kedelai yang diberi pestisida yang berbeda $\left(\mathrm{F}_{2,5}=4,2599, \mathrm{P}_{\text {(perm) }}=0,188\right)$, dan tidak terdapat perbedaan yang nyata pada kekayaan spesies artropoda. Terdapat perbedaan yang nyata pada kelimpahan artropoda antara pertanaman yang menggunakan biopestida dan pertanaman yang menggunakan pestisida pyrethroids sintetik $\left(\mathrm{G}_{6}=284,36, \mathrm{P}<0,0001\right)$, antara pertanaman tanpa pestisida dan pertanaman yang menggunakan pestisida pyrethroids sintetik $\left(G_{6}=2110, P<\right.$ $0,0001)$, dan antara pertanaman tanpa pestisida dan pertanaman yang menggunakan biopestisida
\end{abstract}

\footnotetext{
*Penulis korespondensi: Dwi Ristyadi. Jurusan Agroekoteknologi, Fakultas Pertanian, Universitas Jambi. Jalan Raya Jambi - Muara Bulian, Km 15, Mendalo Darat, 36361

Tel: +628117450327, Email: dristyadi@unja.ac.id
} 
$\left(\mathrm{G}_{6}=2027, \mathrm{P}<0,0001\right)$. Penelitian ini menemukan bahwa penggunaan pestisida sintetik dapat menekan artropoda hama dan artropoda yang menguntungkan, sedangkan penggunaan biopestisida atau tanpa pestisida, secara relatif, dapat memberi peluang kepada artropoda yang menguntungkan untuk berkembang dan sekaligus dapat menekan artropoda hama.

Kata kunci: artropoda, kedelai, pestisida, pertanian organik, pertanian konvensional

\section{INTRODUCTION}

Arthropod community structure in an ecosystem may always change as all components of the community are linked together in complex food webs and info-chemical webs. The causeconsequence cycles of interactions between the biotic components of the ecosystem and also environmental changes occurring at different spatial and temporal scales may affect the mortality, natality, and dispersal of the arthropods in the system. As a result each species may never reach a stable state of population densities (Hanski 1998). The population size of insects is affected by a variety of intrinsic and extrinsic factors that may act in either density-independent or densitydependent manners (Schowalter 2006). Therefore, arthropod populations in an ecosystem are always dynamic.

Arthropod populations in agro-ecosystems tend to be more unstable than in natural ecosystems as the systems and services are simplified, and are regularly disturbed through cropping and tilling regimes (Swift et al. 1996). This situation, in a long run, may seriously affect the population and community structure of on farm insects, and make agroecosystems tend to be more vulnerable to insect pests (Nicholls \& Altieri 2004). Altieri (1987) found considerable evidence that in such artificial systems, the ecological equilibrium is highly variable and human interventions are always needed to prevent destructive oscillations in pest populations. However, human interventions in intensive agriculture may not only bring positive impacts in the agro-ecosystem, but may also create more problems if they are not applied wisely. Pimentel et al. (1992) pointed out that the increased use of pesticides in agriculture has caused environmental and economic problems, like human health problems, animal poisoning and contaminated products, destruction of beneficial organisms, pest resistance, and groundwater and surface water contamination. Therefore, although modern agro-ecosystems have proven capable of producing high yield to humankind, its sustainability is arguable.

Sustainability has become an important issue in agriculture since the 1920s. This was when the rapid growth of industrial based agriculture raised environmental awareness of some people in Europe who pioneered the organic farming movement (Rundgreen 2002). In recent years, a range of different management regimes have been devised and applied in agro-ecosystems, the primary aim of reducing pests' population, minimizing the environmental impacts, and increasing harvestable products from agricultural farms. Generally, all of those management regimes can be put into two broad groups based on their environmental approaches: namely conventional and non-conventional farming.

The term 'conventional farming' refers to the standard, dominant farming approaches practised by most farmers and growers throughout the world, which usually imposes no restrictions on management other than those required by law (Kristiansen \& Merfield 2006). While, "nonconventional" farming systems considered here as either organic or utilizing biologically based management techniques, attempt to minimise the environmental impacts of farming, whilst producing an economically viable crop. This type of management regime emphasizes multi-year management cycles which focus on prevention rather than reaction, and promote selfregulation within an agro-ecosystem (Niemsdorff \& Kristiansen 2006). Conventional and nonconventional farming systems may be similarly vulnerable to population outbreaks of insect pests as both of the systems have altered and disrupted natural conditions of the ecosystem. However, the level of disruption within management regimes may differ as conventional and non-conventional farming have different characteristics. 
Understanding how arthropod community structure changes under different management regimes will be an important tool for assessing the constraints and opportunities of each group of management regimes. For that purpose, this study assessed the effect of different pesticide regimes on the arthropod community structure in soy crops. We expected that the different regime of pesticide (no spray, synthetic pyrethroid, natural pyrethroid) would provide different suppression effects, which in turn would affect the abundance, species richness, and composition of arthropods in an agro-ecosystem over the crop growing season. We expected the no spray treatment to enable a more complex beneficial community to develop, with the natural pyrethroid assemblage starting to mimic that found in the no spray treatment over time. The synthetic pyrethroid assemblage would be showing reduced diversity, but also a much simpler arthropod community structure compared with the other treatments.

The soy crop was chosen as this crop was available at the time of the study. For the purpose of this study, site which use synthetic pyrethroid was considered as conventional farming, while sites which use biopesticides and no use of pesticide were considered as non-conventional farming.

\section{MATERIAL AND METHODS}

\section{Field and laboratory work}

Sampling was carried out between February to April 2011. To assess how arthropod community structure changes among management regimes, samples of arthropods were taken from three sites of soy crops located in the Liverpool Plains Shire in New South Wales, Australia (Figure 1). These crops differed in terms of the management style of the different growers. In detail, one of the soy crops would be (and was) sprayed with broad-spectrum synthetic pesticides - synthetic pyretroids, one site of soy crop would be (and was) sprayed with natural pyrethrum - an organically certified pesticide, and one of the soy crops would not be treated with any pesticides.

Samples of arthropods were collected on three occasions at every site except in the third site of soy crops which was not treated with any pesticides, samplings were taken only on two occasions. This was because the third soy site which would not

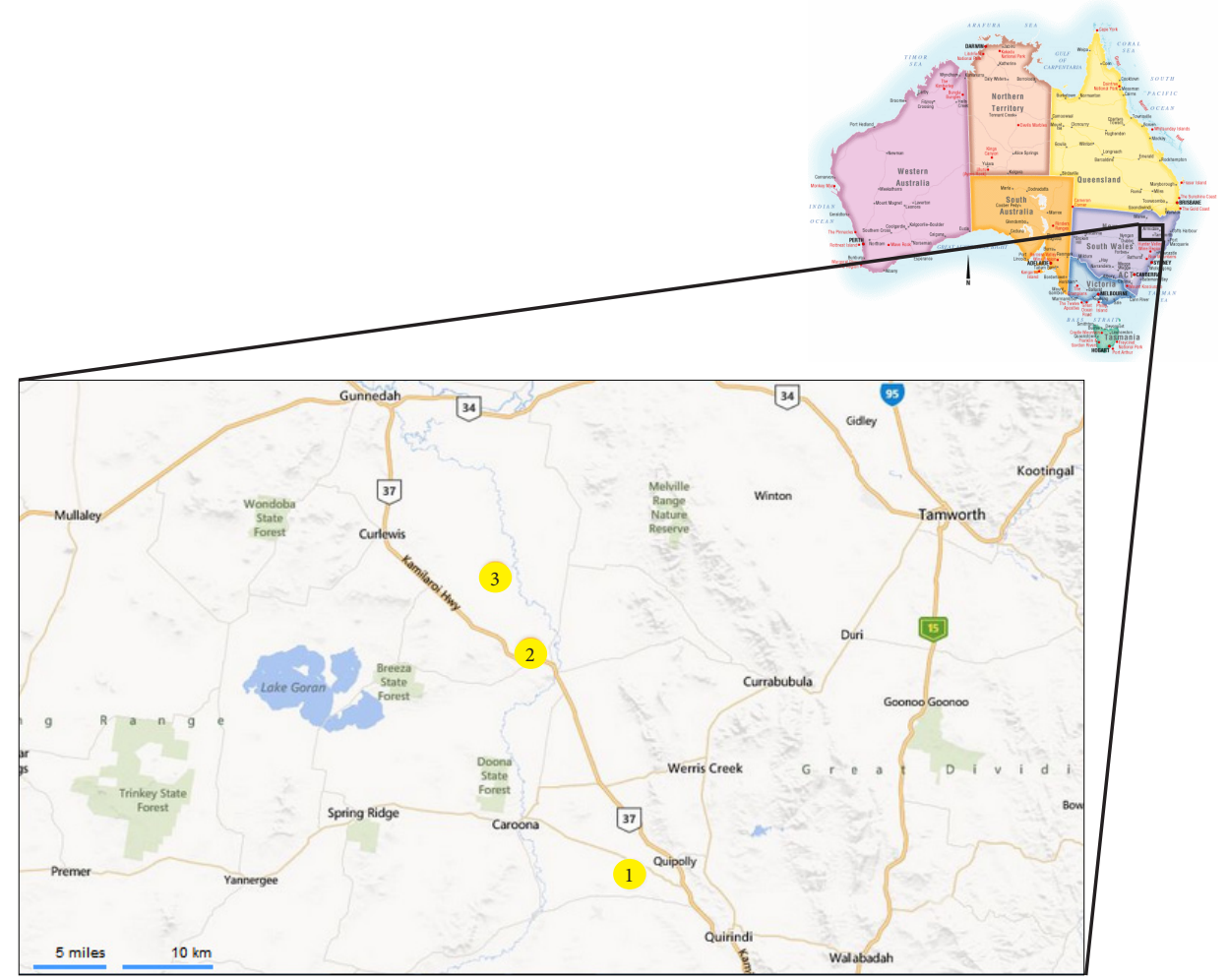

Figure 1. Sites location. Number 1: site treated synthetic pyrethroid; Number 2: site treated with biopesticide (natural pyrethrum); Number 3: non-sprayed site. 
be (and was not) spayed with any pesticides was found later after the first sampling session of other sites. Because there was no pesticide treatment at this site, we considered that we could assume a similar suite of insects would have been in the third soy crop at the time the first samples were taken. This was not ideal but the best that we could do in the situation.

There were three sampling sessions overall for each crop, each session was between two-three weeks apart. The timing for this was dependent on weather conditions, with rainy, wet conditions being common in the summer season of 2011 when the study was conducted. When conditions were wet and cool sampling was avoided as many of the insects were inactive and/or would have got stuck to the plants by surface tension due to their small size and therefore comparisons with a dry crop would have been invalid. All of the soy crops in the three sites have relatively similar growth stage when the sampling were taken.

At every site, samples were taken from four transect points in the middle of the crop, which were between 30-50 hectares in size. Samplings were done using sweep net and beat sheet. Sweep net sampling was done by sweeping over the top of the crop ten times at each transect point. Insects collected in the sweep net were transferred into a plastic bag and kept cool for sorting and identification back in the laboratory. Beat sheet sampling was done by beating the crops for 40 seconds at two points on each transect point, giving eight beat sheet collections within each crop. Larger insects that fell onto the beat sheet were all collected by hand while smaller insects, $<2 \mathrm{~mm}$ body length, were collected using a paintbrush dipped in ethanol. Collections of smaller insects on the beat sheet were limited to two minutes. All beat sheet specimens were kept in alcohol for transport back to the laboratory and sorting and identification. The number of spiders that were found on the beat sheet was also recorded.

All of the collected insects were sorted to individual morphospecies (i.e. a typological species distinguished solely on the basis of morphology). Each morphospecies was placed into feeding groups based on dietary habits. These categories were pest (leaf chewer, leaf/stem miner, sap sucker, midges, mites), beneficial (e.g. predatory, parasitoid) and unknown.

\section{Data analysis}

Arthropod morphospecies were identified from all sites and their respective abundance was recorded. Morphospecies codes were crossreferenced across all sites and samples. Estimates of the total number of species in total, and between treatments were made using the Chao- 1 index in EstimateS8.2 (Colwell \& Coddington 1994; Chao et al. 2000; Colwell 2006). All the data were transformed with $\log (\mathrm{x}+1)$ for further analysis. The transformed data (abundance) were analysed through S17 Bray Curtis similarity to create lower triangular resemblance matrix using Primer 7

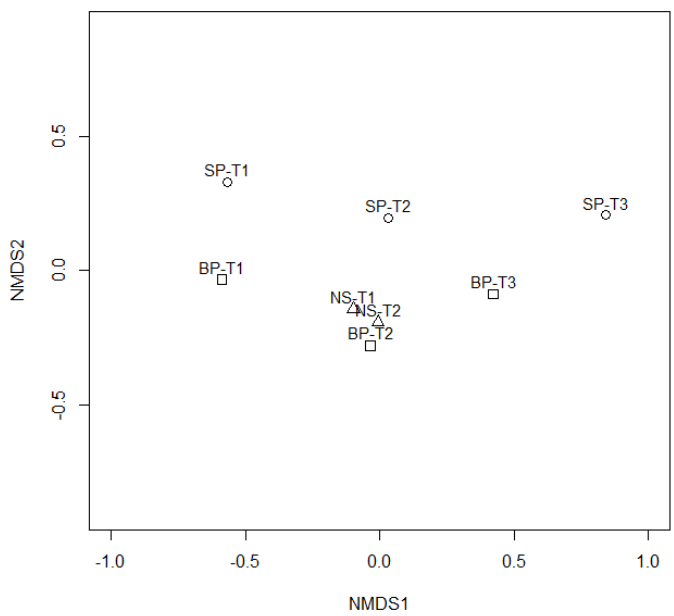

Figure 2. Non-metric multi dimensional scaling (NMDS) ordination plot of all arthropods in soy sites (stress=0.02). SP: site treated with synthetic pesticide (synthetic pyrethroid); BP: site treated with biopesticide (natural pyrethrum); NS: non-sprayed site. Pesticide treatments were applied after the first sampling session [T1]. Data was transformed with $\log (\mathrm{x}+1)$. 
(Clarke \& Gorley 2006). Then, the resemblance matrix was ordinated by using non-metric multidimensional scaling (NMDS), and followed with the distance-based test for homogeneity of multivariate dispersions (PERM-DISP) using PERMANOVA+ (Anderson et al. 2008). Arthropod abundance and species richness data on each different crop were grouped into their feeding guilds before being analysed through the G-test. In this case, G-test analyses were performed as an analogue of a two-sample test of difference (Dytham 2011).

\section{RESULT}

The sampling work conducted at three sites of soy has recorded a total 7991 individuals of arthropod from 180 different morphospecies. The computation of all the arthropod data collected in soy sites with EstimateS 8.2 to assess the completeness of sampling in this study has resulted in ratios between observed and estimated of $73 \%$ for all arthropods, 69\% for beneficials, and 97\% for pests.

The different pesticide regimes applied in the agro-ecosystem have resulted in different levels of change of the arthropods community structure. The site distribution in NMDS ordination plot (Figure 2) implied that the site treated with synthetic pesticide experienced the most extreme change (PERMDISPs $39.9 \pm 4.3$ ), while the site treated with biopesticide experienced intermediate change (PERMDISP $34.8 \pm 2.8$ ), and non-sprayed site was the least (PERMDISP $24.9 \pm 0.0$ ).

The average arthropod abundance of feeding guilds in all soy sites over the study periods were all significantly different: site treated with biopesticide and site treated with synthetic pyrethroid $\left(\mathrm{G}_{6}=284.36, \mathrm{P}<0.0001\right)$; non-sprayed

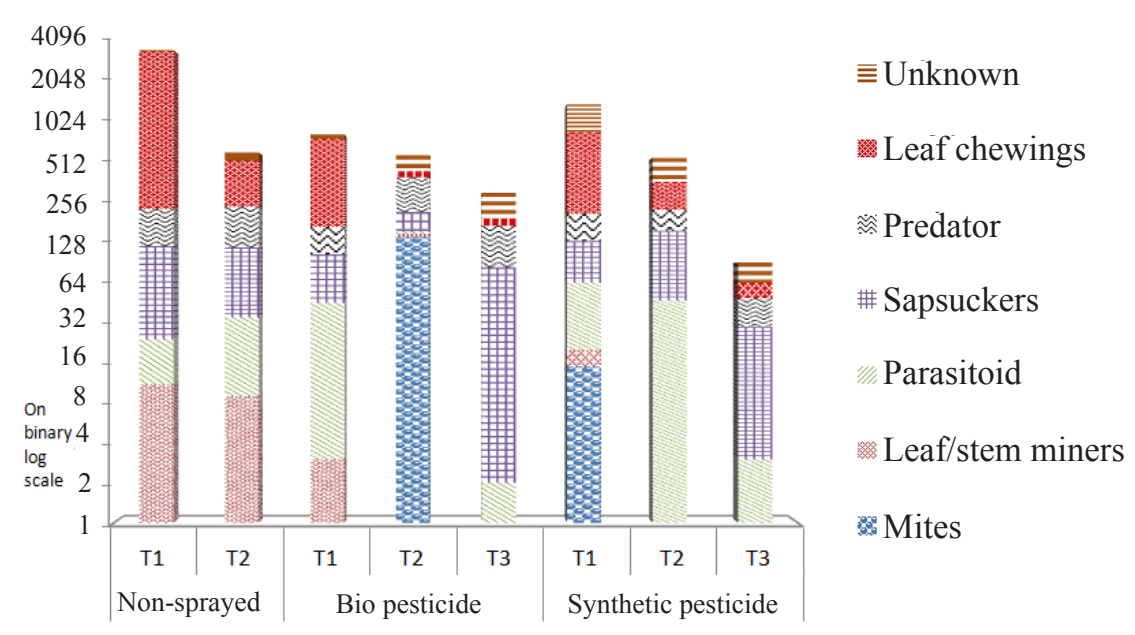

Figure 3. The abundance of arthropod feeding guilds in the soy sites with different treatment. Pesticide treatments were applied after the first sampling time ( $\mathrm{T}=$ Time of sampling).

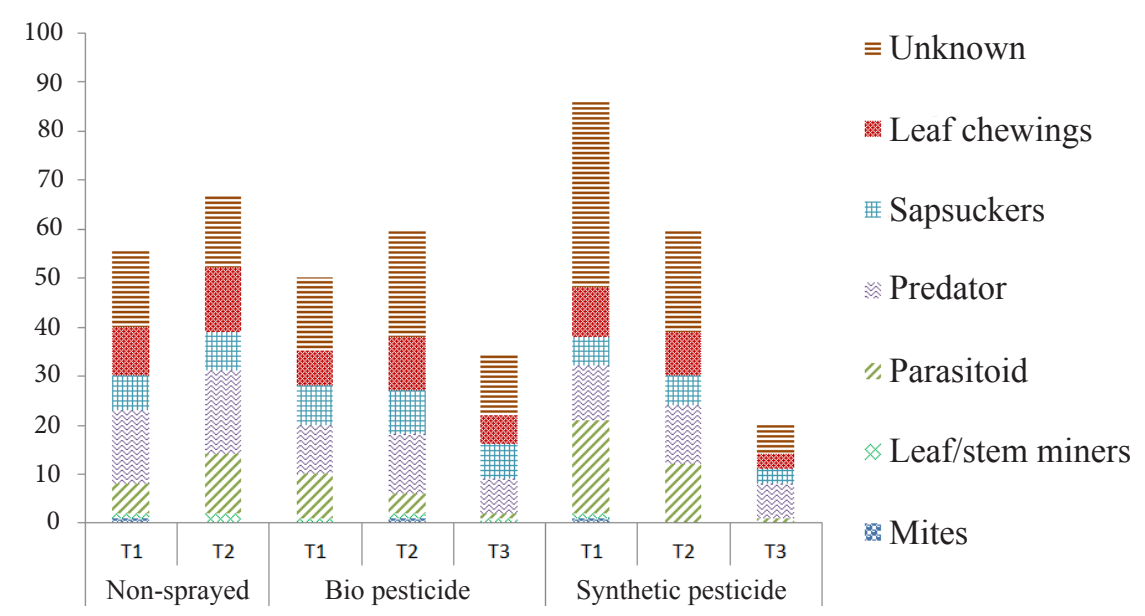

Figure 4. The species richness of arthropods in the soy sites with different treatment. Pesticide treatments were applied after the first sampling time ( $\mathrm{T}=$ Time of sampling). 
site and site treated with synthetic pyrethroid $\left(\mathrm{G}_{6}\right.$ $=2110, \mathrm{P}<0.0001)$; and non-sprayed site to site treated with biopesticide $\left(\mathrm{G}_{6}=2027, \mathrm{P}<0.0001\right)$. Abundance of arthropods at each site varied among the three study times. At all three sites, the total abundance of arthropods decreased over time. This was especially true of the abundance of leaf chewing insects that went down sharply in all sites including where no treatment was applied (soy-ns) (Figure 3). The abundances of other types of arthropods in the untreated site soy$n s$ experienced slight changes at a relatively low level (Figure 3). In contrast, the abundances of other types of arthropods in the site treated with synthetic pyrethroid (soy-sp) and the site treated with natural pyrethroid (soy- $b p$ ) experienced marked fluctuations (Figure 3). After treatment with insecticides, the soy- $b p$ site had more beneficial arthropods (predators), while $s o y$-sp site was dominated by pest arthropods (sap suckers and leaf chewers), however there was a sharp increase in two-spotted mite numbers in the soy- $b p$.

Pairwise comparisons between species richness of arthropods at soy sites were all not significantly different: site treated with biopesticide and site treated with synthetic pyrethroid $\left(\mathrm{G}_{6}=7.157, \mathrm{P}\right.$ $=0.306)$; non-sprayed site and site treated with synthetic pyrethroid $\left(\mathrm{G}_{6}=9.950, \mathrm{P}=0.127\right)$; and non-sprayed site to site treated with biopesticide $\left(\mathrm{G}_{6}=4.840, \mathrm{P}=0.564\right)$. There were different trends in the changes of species richness during the sampling session between all the three sites. In general, soy-sp experienced downward trends, and soy-bp experienced fluctuated trends in the total number of arthropod species, while there were upward trends of arthropod diversity level in soy-ns sites (Figure 4). At the end of the sampling period, soy-sp site had the lowest number of arthropod species while soy-ns site had the highest arthropod species richness.

\section{DISCUSSION}

This present study found that the broad spectrum synthetic pesticide (synthetic pyrethroid) has severely affected all organisms in an agroecosystem more than the natural pesticide did, although the biopesticide (natural pyrethroid) used in the studied site was also non selective in term of its toxicity. Further analysis on the collected arthropod data revealed that changes in arthropod community structure within the three sites with different pesticide regimes were only significantly different in term of arthropod abundance but not in species richness. The lack of differences in species richness between conventional and nonconventional farm has been earlier demonstrated by other studies (Weibull et al. 2003). Nonetheless, Hillebrand et al. (2008) found evidence that the relative abundance of species (species evenness) and species richness has a similar broad range of ecological impacts which may determine ecosystem health, although the effects of species evenness on ecology often received far less attention.

Instead of being significantly different, the abundance of arthropods in all sites decreased over the sampling time (Figure 3). This study found that leaf chewing insects experienced the most extreme temporal change which went down sharply in all studied sites, these results show that the regulation effects of the different management regimes assessed in this study, including where no pesticide treatment was applied (soy-ns), may potentially protect crops by reducing herbivore arthropod population size. Similarly, a study by Letourneau and Goldstein (2001) demonstrated that there was no significant difference in overall pest damage between organic and conventional farming.

Furthermore, sites using synthetic pyrethroid had a lower number of arthropods at the end of the sampling season compared with biopesticides and no pesticides. These different rates of efficacy may be related to the fundamental properties which make synthetic pesticides become toxic to all organisms, more resistant to environmental degradation, and provide long term impacts on agro-ecosystems (Connell \& Miller 1984). In contrast, natural pyrethrum that was used as a biopesticide in this study, although may causing knockdown and death on arthropods, is a low toxicity compound with acute oral $\mathrm{LD}_{50}$ to rats of $>2000 \mathrm{mg} \mathrm{kg}^{-1}$, and has limited field persistence because of the compound's photo-instability (Copping \& Menn 2000). Thus, the application of natural pesticides on agro-ecosystems may not impact all arthropods as it only kills arthropods 
that it makes direct contact with, before breaking down.

Synthetic pyrethroid treatment has also reduced the abundance of predator and parasitoid arthropod, whereas there was an increase of predator and parasitoid abundance and a decrease of herbivore abundance (leaf chewer, leaf/stem miner, sap sucker, and mites) when there was no pesticide treatment. At the site with the biopesticide treatment, predator abundance increased about $100 \%$ before steadily declining back following the decrease of herbivore abundance. A similar result has been found by Crowder et al.(2010) that nonconventional farming practices, with or without biopesticide, promote the relative abundance of species (evenness) among natural enemies which may, to some extent, potentially suppress the pest population. This is possible as biological pest control in organic farming is designed to work in harmony with nature by maintaining a healthy population size of predatory and parasitoid arthropods (Scialabba \& Hattam 2002). These results indicated that the lack of synthetic pesticide inputs in non-conventional/organic farming system, to some extent, may provide a chance for various arthropods to thrive and compete in the system. Admittedly, this study cannot provide robust evidence of predators' suppression effect on pest population.

Although there were no significant differences in term of species richness between the sites with different pesticide regimes, the trends of species richness changes indicated that the application of synthetic pesticides may reduce arthropod species richness in an agro-ecosystem (Figure 4). This trend of declining biodiversity has previously been demonstrated by many others studies as strongly related to the intensive use of pesticides which may cause short-term and long-term effects on the food chains (Isenring 2010). A study by Geiger et al.(2010) found consistent negative effects of synthetic pesticide on biodiversity which reduce the biological control potential in agro-ecosystems. Similarly, this present study found a sharp decline in parasitoid diversity as affected by synthetic pyrethroid. Thus, the loss of biodiversity in the long run as affected by pesticide use may make the agro-ecosystem become more susceptible to pest outbreaks.
The non-conventional farming approaches without pesticide application have resulted in an upward trend of species richness of almost all function groups (predator, parasitoid, leaf cheawer, leaf/stem miner, and sap sucker) of the arthropods in the system. Indeed, organic practices which rely on natural or naturally derived pest controls will not only promote beneficial arthropods but also herbivorous arthropods. However, Letourneau and Goldstein (2001) found evidence that non-conventional farming practices significantly promote the conservation of all function groups of arthropods which means that the 'complementarities' of herbivores could result in a dilution effect of lower damage levels by pest species.

\section{CONCLUSION}

The use of synthetic pesticides in agriculture has been the most powerful tool in regulating arthropod populations in order to avoid crops losses. However, as this has been found in this study that all of the beneficial arthropods were also suppressed with this synthetic pyrethroid, it become arguable that in the long run this approach may be unsustainable and lead to more severe pest problems. On the other hand, the more environmentally friendly approaches in controlling pests in agriculture, like using biopesticides or even totally avoiding the pesticides have been found only caused moderate effects on arthropods community structure as they provide a chance for various arthropods to thrive and compete in the system.

This study was unable to assess the crop damage caused by pests in both systems. Therefore, further study on assessing the crop losses as affected by different management regimes combined with economical analysis of these approaches is needed in order to provide useful information for growers.

\section{ACKNOWLEDGEMENT}

We thank to The Australian Government for providing the funding, and anonymous grains growers in the Liverpool Plains Shire who allowed us to access their properties for this project. 


\section{REFERENCES}

Altieri MA. 1987. Agroecology. London: Intermediate Technology Publications.

Anderson M, J, Gorley R, N, Clarke K, R. 2008. PERMANOVA + for PRIMER: Guide to software and statistical methods. Plymouth: PRIMER-E.

Chao A, Hwang WH, Chen YC, Kuo CY. 2000. Estimating the number of shared species in two communities. Statistica Sinica 10:227-246.

Clarke KR, Gorley RN. 2006. Primer V8 user manual/tutorial. Plymouth: PRIMER-E.

Colwell RK. 2006. EstimateS: Statistical estimation of species richness and shared species from samples. (Software and User's Guide).

Colwell RK, Coddington J. 1994. Estimating terresterial biodiversity through extrapolation. Philosophical Transactions of the Royal Society London, Series B: Biological Science 35:101-118. doi: http://dx.doi.org/10.1098/rstb.1994.0091.

Connell DW, Miller GJ. 1984. Chemistry and ecotoxicology of pollution. United States: Wiley.

Copping LG, Menn JJ. 2000. Biopesticides: a review of their action, applications and efficacy. Pest Management Science 56:651-676. doi: http:// dx.doi.org/10.1002/1526-4998(200008)56:8<651 ::AID-PS201>3.0.CO;2-U.

Crowder DW, Northfield TD, Strand MR, Snyder WE. 2010. Organic agriculture promotes evenness and natural pest control. Nature 466:109-112. doi: http://dx.doi.org/10.1038/nature09183.

Dytham C. 2011. Choosing and using statistics: A biologist's guide. United States: John Wiley \& Sons.

Geiger F, Bengtsson J, Berendse F, Weisser WW, Emmerson M, Morales MB, Ceryngier P, Liira J, Tscharntke T, Winqvist C, Eggers S, Bommarco $\mathrm{R}$, Pärt $\mathrm{T}$, Bretagnolle $\mathrm{V}$, Plantegenest $\mathrm{M}$, Clement LW, Dennis C, Palmer C, Oñate JJ, Guerrero I, Hawro V, Aavik T, Thies C, Flohre A, Hänke S, Fischer C, Goedhart PW, Inchausti P. 2010. Persistent negative effects of pesticides on biodiversity and biological control potential on European farmland. Basic and Applied Ecology 11:97-105. doi: http://dx.doi.org/10.1016/j. baae.2009.12.001.

Hanski I. 1998. Spatial structure and dynamics of insect populations. In: Demster JP, McLean IFG (Eds.), Insects Populations; In theory and in practice. pp. 3-27. Dordrecht, The Netherlands: Kluwer Academic Publishers. doi: http://dx.doi. org/10.1007/978-94-011-4914-3_1.
Hillebrand H, Bennett DM, Cadotte MW. 2008. Consequences of dominance: a review of evenness effects on local and regional ecosystem processes. Ecology 89:1510-1520. doi: http:// dx.doi.org/10.1890/07-1053.1.

Isenring R. 2010. Pesticides and the loss of biodiversity. Brussels: Pesticide Action Network Europe.

Kristiansen P. 2006. Overview of organic agriculture. In: Kristiansen P, Taji A, Reganold J (Eds.), Organic Agriculture: a Global Perspective. pp. 1-23. Collingwood: CSIRO.

Letourneau D, Goldstein B. 2001. Pest damage and arthropod community structure in organic vs. conventional tomato production in California. Journal of Applied Ecology 38:557-570. doi:http:// dx.doi.org/10.1046/j.1365-2664.2001.00611.x.

Nicholls CI, Altieri MA. 2004. Agroecological bases of ecological engineering for pest management. In: Guerr GM, Wratten SD, Altier MA. (Ed.), Ecological Engineering for Pest Management: Advances in Habitat Manipulation for Arthropods. pp.33-54. Collingwood: CSIRO Publishing.

Niemsdorff PF, Kristiansen P. 2006. Crop agronomy in organic agriculture. In: Kristiansen P, Taji A, Reganold J (Eds.), Organic Agriculture: a Global Perspective. pp. 53-82. Collingwood: CSIRO Publishing.

Pimentel D, Acquay H, Biltonen M, Rice P, Silva M, Nelson J, Lipner V, Giordano S, Horowitz A, D'Amore M. 1992. Environmental and economic costs of pesticide use. BioScience 42:750-760. doi: http://dx.doi.org/10.2307/1311994.

Schowalter TD. 2006. Insect Ecology: an Ecosystem Approach. United States: Academic Press.

Scialabba N, Hattam C. 2002. Organic agriculture, environment and food security. Rome: Food and Agriculture Organization of the United Nations.

Swift MJ, Vandermeer J, Ramakrishnan PS, Anderson JM, Ong CK, Hawkins BA. 1996. Biodiversity and agroecosystem function. In: Mooney HA, Cushman JH, Medina E, Sala OE, Schulze ED (Eds.), Functional Role of Biodiversity: A Global perspective. pp. 261-298. Universitas Michigan: John Wiley \& Sons Ltd.

Weibull A-C, Östman Ö, Granqvist Å. 2003. Species richness in agroecosystems: the effect of landscape, habitat and farm management. Biodiversity and Conservation 12:1335-1355. doi: http://dx.doi.org/10.1023/ A:1023617117780. 